\title{
Recent advances in bioreactors for cell-based therapies
}

\section{[version 1; peer review: 2 approved]}

\author{
Makeda Stephenson 1,2, Warren L. Grayson (iD1-4 \\ ${ }^{1}$ Translational Tissue Engineering Center, Johns Hopkins University School of Medicine, Baltimore, Maryland, USA \\ ${ }^{2}$ Department of Biomedical Engineering, Johns Hopkins University School of Medicine, Baltimore, Maryland, USA \\ ${ }^{3}$ Department of Materials Science and Engineering, Johns Hopkins University, Baltimore, Maryland, USA \\ ${ }^{4}$ Institute for NanoBioTechnology, Johns Hopkins University, Baltimore, Maryland, USA
}

V1 First published: 30 Apr 2018, 7(F1000 Faculty Rev):517

https://doi.org/10.12688/f1000research.12533.1

Latest published: 30 Apr 2018, 7(F1000 Faculty Rev):517

https://doi.org/10.12688/f1000research.12533.1

\section{Abstract}

Bioreactors have become indispensable tools in the cell-based therapy industry. Various forms of bioreactors are used to maintain wellcontrolled microenvironments to regulate cell growth, differentiation, and tissue development. They are essential for providing standardized, reproducible cell-based products for regenerative medicine applications or to establish physiologically relevant in vitro models for testing of pharmacologic agents. In this review, we discuss three main classes of bioreactors: cell expansion bioreactors, tissue engineering bioreactors, and lab-on-a-chip systems. We briefly examine the factors driving concerted research endeavors in each of these areas and describe the major advancements that have been reported in the last three years. Emerging issues that impact the commercialization and clinical use of bioreactors include (i) the need to scale up to greater cell quantities and larger graft sizes, (ii) simplification of in vivo systems to function without exogenous stem cells or growth factors or both, and (iii) increased control in the manufacture and monitoring of miniaturized systems to better capture complex tissue and organ physiology.

\section{Keywords}

Bioreactors, stem cell manufacturing, tissue-on-a-chip

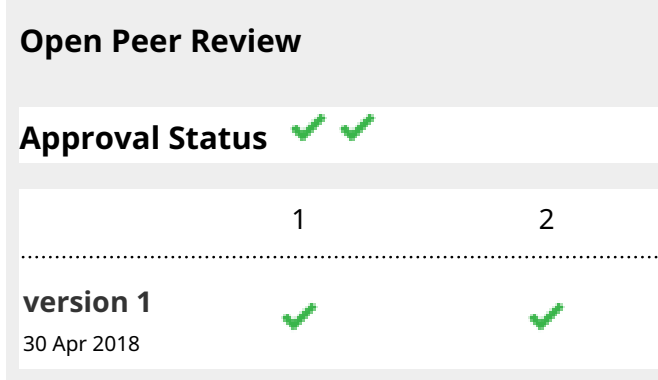

Faculty Reviews are review articles written by the prestigious Members of Faculty Opinions. The articles are commissioned and peer reviewed before publication to ensure that the final, published version is comprehensive and accessible. The reviewers who approved the final version are listed with their names and affiliations.

1. Teng Ma, Florida State University,

Tallahassee, USA

2. Liesbet Geris, KU Leuven, Leuven, Belgium University of Liège, Liège, Belgium

Ioannis Papantoniou, KU Leuven, Leuven, Belgium

Priyanka Gupta, KU Leuven, Leuven, Belgium

Any comments on the article can be found at the end of the article. 
Corresponding author: Warren L. Grayson (wgrayson@jhmi.edu)

Author roles: Stephenson M: Writing - Original Draft Preparation, Writing - Review \& Editing; Grayson WL: Writing - Original Draft Preparation, Writing - Review \& Editing

Competing interests: Makeda K. Stephenson declares that she has no competing interests. Warren L. Grayson owns stock in EpiBone.

Grant information: This work was supported by Maryland Stem Cell Research Funding (2016-MSCRFI-2692).

The funders had no role in study design, data collection and analysis, decision to publish, or preparation of the manuscript.

Copyright: @ 2018 Stephenson M and Grayson WL. This is an open access article distributed under the terms of the Creative Commons Attribution License, which permits unrestricted use, distribution, and reproduction in any medium, provided the original work is properly cited.

How to cite this article: Stephenson M and Grayson WL. Recent advances in bioreactors for cell-based therapies [version 1; peer review: 2 approved] F1000Research 2018, 7(F1000 Faculty Rev):517 https://doi.org/10.12688/f1000research.12533.1

First published: 30 Apr 2018, 7(F1000 Faculty Rev):517 https://doi.org/10.12688/f1000research.12533.1 


\section{Introduction}

Bioreactors provide controlled delivery of nutrients and biomimetic stimuli in order to influence cell growth, differentiation, and tissue formation. They have been extensively used to promote the expansion of red blood cells, chimeric antigen receptor (CAR) $\mathrm{T}$ cells, induced pluripotent stem cells, and mesenchymal stem cells. Additionally, the ability to control the spatiotemporal delivery of the biological, biochemical, and biophysical signals that regulate tissue development confers a number of advantages for engineering $3 \mathrm{D}$ tissues relative to standard cell culture techniques by providing well-defined conditions to regulate cell behaviors. These advantages include (i) improved standardization and reproducibility, (ii) scale-up to larger, clinically relevant tissue grafts or cell expansion scales, (iii) superior functionality compared with $3 \mathrm{D}$ grafts cultured in tissue culture flasks, and (iv) improved systems for testing cell responses to a range of experimental parameters. As the field of regenerative medicine has matured, the number of applications has increased and the roles that bioreactors play in enabling the commercialization and clinical translation of stem cell-based technologies have become more defined. In this review, we will provide a critical overview of biomedical applications of bioreactors and discuss current trends and recent advances that promote the application of bioreactor technologies for single-cell manufacture, production of engineered tissue grafts, and drug screening.

\section{Bioreactors for cell proliferation and differentiation}

The therapeutic promise of stem cell-based technologies for the treatment of pathologies ranging from hair $\operatorname{loss}^{1}$ to blindness ${ }^{2}$ has precipitated the need for a cell-manufacturing sector to provide therapeutic allogeneic cells. Owing to the extensive infrastructure requirements and rigorous standards defined by regulatory agencies, the cost will likely be too burdensome for traditional hospitals and treatment centers and will manifest as centralized facilities that specialize in providing high-quality cells with verifiable characteristics. However, cell-based therapies often require the application of vast quantities of cells $\left(10^{8}-10^{10}\right)$ in order to be effective. A practical limitation arises as the amount of space required to grow these large quantities of cells using standard cell culture apparatus is prohibitive. This has spawned a demand for bioreactors capable of supporting industrial-scale, ultra-high-density cell suspension cultures with controlled microenvironments, standardization, and uniformity of culture conditions in order to generate homogenous populations of stem or lineage-specific cells. A few types of bioreactors have been employed to generate large populations of phenotypically defined cells. Variable designs have been employed for adherent versus non-adherent cells and to account for differences in cellular responses to microenvironmental cues. Table 1 summarizes several bioreactor types that have been used for cell expansion.

\section{Adhesion-dependent cell types}

Since many therapeutically relevant cells are adhesion dependent and thus cannot be readily grown in suspension cultures, the scale-up of cell manufacture presents a unique challenge. To overcome this obstacle, biomaterial technologies have been combined with bioreactors to support the development of highdensity bioreactor conditions. For adherent cells, suspension culture can be achieved by the use of hollow fibers in perfusion systems, encapsulation, or microspheres (also known as microcarriers), which increase the surface area of a suspension bioreactor $^{3}$. Packed bed bioreactors have also been used to enable both isolation and expansion of mesenchymal stem cells ${ }^{4,5}$. Specifically, studies have shown that adherent cells such as bone marrow-derived mesenchymal stem cells can be cultured on protein-coated microspheres. Cells grown in this manner can retain their functional markers and viability ${ }^{3}$. With this strategy, it is possible to scale the volumes of cell cultures up to the order of $10^{2}-10^{3} \mathrm{~L}$ and stand-alone systems such as the Mobius (EMD Millipore) stirred-tank bioreactor series are commercially available in sizes ranging from 50 to $2,000 \mathrm{~L}$. At this scale, the impeller speeds required to maintain homogenous distribution of metabolites generate turbulent flows and large shear forces, which induce spontaneous differentiation of stem cells. In order to mitigate this effect, studies have focused on either optimizing agitation schemes ${ }^{6,7}$ or encapsulating cells in microspheres ${ }^{8,9}$. Although these strategies are promising for providing commercially available therapeutic cells, the high cost of reagents and growth factors restricts the use of industrial-scale systems in scientific exploration $^{10}$.

Published studies of bioreactor cultures of mesenchymal- and adipose-derived stem cells typically report data for bioreactors with maximum volumes of $3 \mathrm{~L}^{11,12}$, although Lawson et al. demonstrated the ability of these systems to safely and effectively enable a 43-fold cell expansion over 11 days using a $50 \mathrm{~L}$ volume bioreactor with a graduated agitation and feeding scheme ${ }^{11}$. The cells retained their tri-lineage pluripotency, T-cell modulation behavior, and phenotypic markers, including CD44 and CD90, when compared with cells cultured under traditional conditions $^{11}$. However, these studies used growth factors and animal serum in their media. The development of defined media without supraphysiological concentrations of growth factors in cell culture would promote economically feasible industrialscale culture. Another key shortcoming is the dearth of in vivo efficacy data from cells produced in these large-scale bioreactors.

Another strategy for enhancing the therapeutic effectiveness of mesenchymal- and adipose-derived stem cells has been to deliver them as self-assembled aggregates. These cellular spheroids exhibit enhanced survival and tissue-forming properties ${ }^{13-15}$. The impact of bioreactors on mesenchymal stem cell aggregation kinetics and spheroid size has recently been studied by using commercially available WAVE Bioreactors ${ }^{\mathrm{TM}}$, which provide gentle stirring and single-use bags for scale-up ${ }^{16}$. The authors used a combination of experimentation and modeling to demonstrate that a tightly controlled size distribution of cellular aggregates with enhanced therapeutic characteristics could be obtained.

\section{Induced pluripotent stem cell expansion}

Suspension aggregate cultures in rotating flasks, rotating wall bioreactors, stirred-tank bioreactors, and WAVE Bioreactors ${ }^{\mathrm{TM}}$ have become the primary means for the expansion of embryonic 


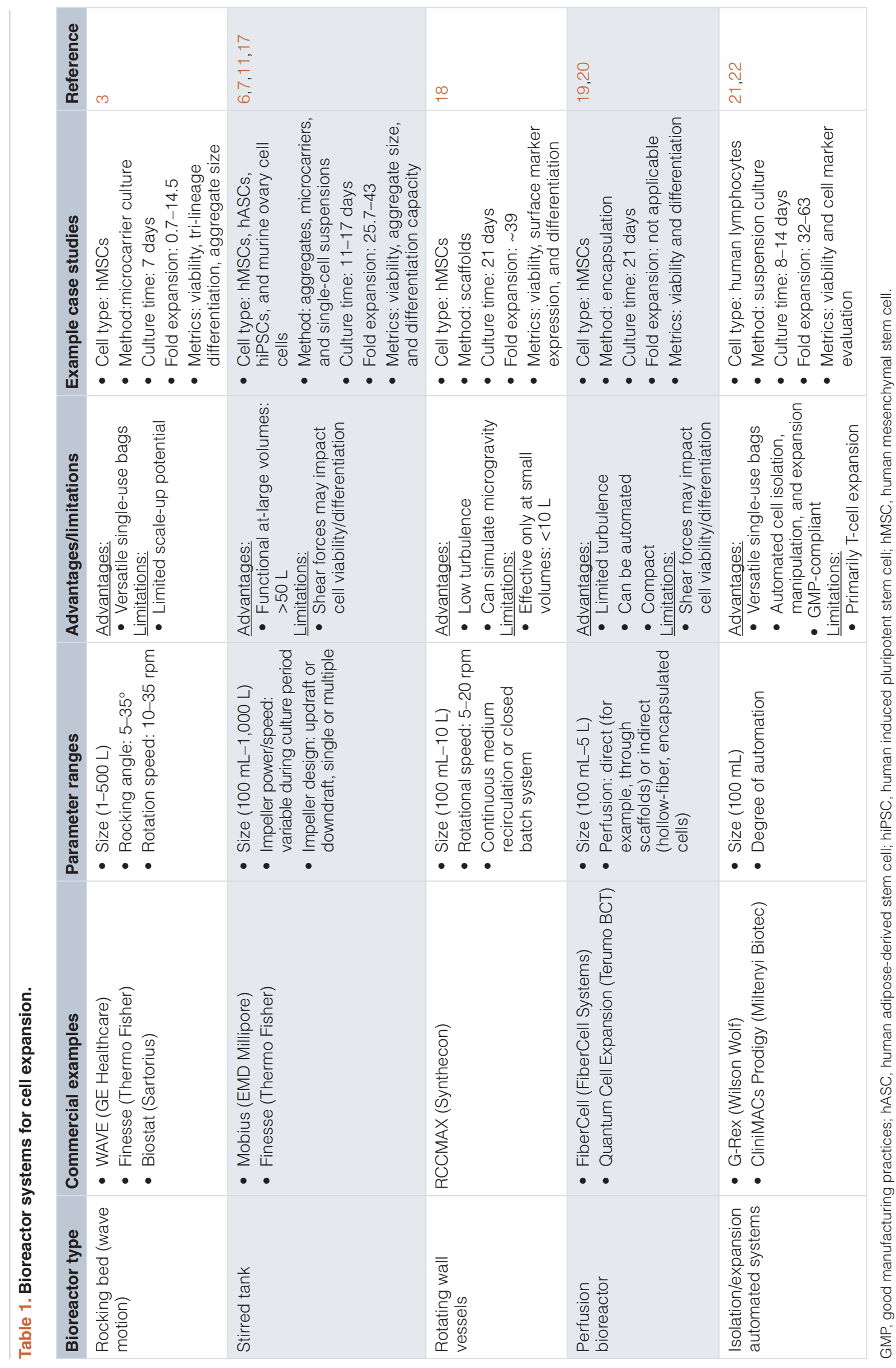


stem cells or induced pluripotent stem cells (reviewed in 23,24). Aggregate cultures are thought to more closely mimic the native microenvironment (inner cell mass) of pluripotent cells. Owing to their high differentiation capacity, the microenvironmental conditions for pluripotent cells-including aggregate size - must be tightly regulated in order to maintain an undifferentiated phenotype. The aggregate sizes are regulated by chemical (Rho-kinase [ROCK] inhibitors) and mechanical (shear forces or physical disruption) techniques. In addition, the dissolved oxygen concentrations and dilution rate impact the differentiated state of the cells ${ }^{25}$. Using this continuous expansion method in a stirred-tank bioreactor, Abecasis et al. demonstrated 1,100-fold expansion in 11 days using 4\% dissolved oxygen $^{25}$. The resulting cells were characterized by using proteomic and gene stability analysis as well as proliferation and gene expression assays to validate their naïve state ${ }^{25}$.

\section{CAR T-cell expansion}

The use of CAR T cells and other immune cells such as natural killer cells is an important emerging therapy for treating diseases of the immune system and is being applied to patient-specific treatment of cancer $^{26}$. CAR T-cell therapy uses autologous $\mathrm{T}$ cells expanded to therapeutic volumes (liter scale) in rocking bed, disposable bag bioreactors such as WAVETM or CultiBag bioreactors. Technologies for the automated or semi-automated processing of CAR $\mathrm{T}$ cells are commercially available and include the CliniMACS Prodigy, DynaMag, and G-Rex systems ${ }^{27}$.

Recent published studies demonstrate the ability of isolation and transduction protocols to be scaled up to clinical production in ways that comply with good manufacturing practices and clinical regulatory standards. These studies focused on optimizing production processes and verifying and characterizing the products using the automated CliniMACS Prodigy system $^{21,22}$.

\section{Quality criteria for cell-based products}

Finally, cell products from bioreactors must be evaluated in a standardized manner to ensure quality control. The International Society for Cell Therapy and the European Society for Blood and Marrow Transplantation publish joint quality guidelines for identifying cell products ${ }^{28,29}$. These may include key release criteria such as surface marker analysis, proteomics, functional assays, and sterility testing.

\section{Advances in tissue engineering bioreactors}

In contrast to bioreactors that produce single cells, tissue engineering bioreactors have supported the development of large 3D tissue grafts. To produce large (centimeter-sized) viable grafts, these systems often use convective flow to provide crucial mass transport regimes, overcome the diffusional limitations of nutrients and oxygen, and prevent the accumulation of metabolic waste products that otherwise induce starvation and death of the cells in the inner regions of the construct. Tissue engineering bioreactors can also enhance the functionality of grafts through the application of biomimetic physiological stimuli as well as the incorporation of sensors that give real-time feedback of culture conditions. After incubation, the mature, functional cellular constructs can be transplanted in vivo to regenerate damaged tissues. Tissue engineering bioreactors will likely play a significant role in translating engineered grafts to the clinic as the potential automation renders them economically efficient and amenable to mass production for larger populations of patients.

Cutting-edge research in this field continues to focus on the improved application of biophysical stimuli to optimize functional tissue assembly ${ }^{30-35}$ and computational modeling to improve predictability of the outcomes ${ }^{19,36,37-40}$. Additionally, notable efforts to enhance the clinical applicability of these grafts have focused on engineering grafts that are similar in size to critical-sized bone defects in humans and are tailored to the patient ${ }^{20,41,42}$. Nguyen et al. recently demonstrated the ability to culture a $200 \mathrm{~cm}^{3}$ cell-based construct in vitro without the development of necrotic centers ${ }^{20,42}$. In this approach, bone marrow-derived mesenchymal stem cells were encapsulated in hydrogel beads and placed in a tubular perfusion bioreactor. Three-dimensional-printed molds that could be anatomically shaped were used to direct the flow through the hydrogel beads. The space between the hydrogel beads enhanced mass transport to the cells throughout the entire construct, allowing the stem cells to remain viable and undergo osteogenic differentiation. Although this approach represents a critical advancement in the culture of clinically sized constructs, it remains limited by the use of hydrogel beads that minimize cell-cell interactions and inhibit paracrine signaling between cells, which are important factors in bone formation. In contrast, Bhumiratana et al. directly seeded adipose-derived stem cells into the pore spaces of anatomically shaped, porcine temporomandibular joint scaffolds ${ }^{41}$. They cultured the adipose-derived stem cell-seeded scaffolds in perfusion bioreactors for 3 weeks in vitro before using the bioreactors to maintain their viability during transport to an on-site animal facility. The grafts-customized for each pig-were implanted and cultured for up to 6 months in vivo. This was a foundational, proof-of-concept study and clearly demonstrated the feasibility of using this strategy as a treatment for humans. However, in general, there remains a huge gap in the growth of 3D engineered tissues in bioreactors and demonstration of in vivo functional integration and potency.

\section{In vivo bioreactors}

In spite of the inherent advantages of using tissue engineering bioreactors to grow entire grafts that are primed for implantation into defect sites, there are a number of practical barriers to clinical translation associated with extended ex vivo culture. One major limitation is that the large, volumetric grafts often lack an intact vasculature, which consequently hampers their post-transplantation viability. To overcome these limitations, an alternative approach known as "in vivo bioreactors" has been employed. Unlike the systems described above, the in vivo bioreactor, despite the use of the "bioreactor" terminology, does not incorporate robust design principles or the development of 
new equipment. There is no hardware, and the success of the strategy is highly dependent on surgical expertise and manipulation. Rather, it primarily refers to a pocket within the body into which biomaterials or immature tissue engineered constructs are surgically implanted and incubated for an extended period of time. Within these pockets (for example, omentum or muscle flap), the grafts harness the regenerative capacity of the body to become fully vascularized. Key advantages of this method include the presence of naturally occurring cytokines and other factors, the establishment of neovasculature and nervous tissue within the implant, and immune compatibility ${ }^{43}$. The primary application of the in vivo bioreactor principle has been for the development of critical-sized bone grafts. Several recent studies have demonstrated the use of prefabricated bone grafts which are either incubated in situ or vascularized by extended implantation in muscle or omentum or anastomosed with large arteries ${ }^{43-53}$ and may be feasible even without the use of transplanted stem cells or growth factors.

\section{Organ-on-a-chip bioreactors}

As the previous examples illustrate, bioreactors typically have been employed to address challenges of scale-up. However, miniaturized tissues created by using microfluidic bioreactors facilitate efficient, inexpensive, high-throughput drug screening or disease modeling. Microfluidic bioreactors-often referred to as lab-on-a-chip systems-use minute quantities of cells grown together in micrometer-scaled wells. Microliter volumes of fluid are pumped to the cells through channels that allow the effects of multiple concentrations of growth factors or pharmacological agents to be rapidly tested. Often, modified cells are used to permit easily monitored parameters (such as fluorescence ${ }^{54}$ ) to be used as read-outs of cellular responses. Early modifications to these systems enabled the use of high-density $3 \mathrm{D}$ cell culture using multi-cell aggregates, microspheres, and cell encapsulation to better recapitulate the cell-cell interactions of native tissues in ways not possible in 2D culture. Even so, it is challenging to replicate the impact of pharmacological agents on the complex functions of tissues, such as the lung or heart, in these simplified systems. Hence, more recent versions of lab-on-a-chip bioreactors have incorporated physiological factors such as airflow and mechanical stimulation that mimic breathing ${ }^{55,56}$ or have integrated vasculature and direct blood flow with contractile cardiac cells $\mathrm{s}^{57}$. These two technologies, which are currently being commercialized, more accurately capture physiological responses to specific stimuli while retaining the benefits of simplicity and low cost.
The most recent developments in the field of lab-on-a-chip technology have focused on increasing the ease of use. For example, researchers are investigating methods to 3D print and seed an entire chip in a single pass ${ }^{54,58}$. Other teams have developed smartphone-based systems to monitor the internal environment ${ }^{59}$ and hybrid materials which allow point-by-point manipulation of the cells within the bioreactor ${ }^{60}$. Perhaps one of the most significant advantages of lab-on-a-chip systems is their ability to capture complex physiology of multiple organ systems. Lee et al. ${ }^{61}$ and Shirure and George ${ }^{62}$ reported on the development of pumpless, dual-organ bioreactor systems. Current trends portend the advent of more advanced human-on-a-chip systems, which will test on- and off-target effects of drugs on multiple organ systems.

\section{Conclusions}

Bioreactors fill a critical niche in the commercialization and clinical translation of cell-based therapies and drug-testing platforms. Current trends suggest an increased emphasis on manufacturing needs. This includes scaling up of suspension culture bioreactors to industrial sizes and modifications of tissue engineering bioreactors to enable the formation of patientspecific grafts that are of therapeutically relevant sizes. In spite of the many scientific and technical advantages of these systems, regulatory requirements may prove to be significant barriers to their clinical application. For lab-on-a-chip systems, major advancements in monitoring, control, and fabrication techniques are resulting in progressively more complex systems that more closely mimic human physiology and capture the interactions of multiple organs. The establishment of low-cost platforms will have a significant beneficial impact on the future of disease modeling and drug testing.

\section{Competing interests}

Makeda K. Stephenson declares that she has no competing interests. Warren L. Grayson owns stock in EpiBone.

\section{Grant information}

This work was supported by Maryland Stem Cell Research Funding (2016-MSCRFI-2692).

The funders had no role in study design, data collection and analysis, decision to publish, or preparation of the manuscript.
1. Ali N, Zirak B, Rodriguez RS, et al: Regulatory T Cells in Skin Facilitate Epithelial Stem Cell Differentiation. Cell. 2017; 169(6): 1119-1129.e11. PubMed Abstract | Publisher Full Text | Free Full Text

2. Schwartz SD, Regillo CD, Lam BL, et al:: Human embryonic stem cell-derived retinal pigment epithelium in patients with age-related macular degeneration and Stargardt's macular dystrophy: follow-up of two open-label phase 1/2 studies. Lancet. 2015; 385(9967): 509-16. PubMed Abstract | Publisher Full Text

3. F Shekaran A, Lam A, Sim E, et al.: Biodegradable ECM-coated PCL microcarriers support scalable human early MSC expansion and in vivo bone formation. Cytotherapy. 2016; 18(10): 1332-44. PubMed Abstract | Publisher Full Text | F1000 Recommendation 
4. Timmins NE, Kiel M, Günther M, et al:: Closed system isolation and scalable expansion of human placental mesenchymal stem cells. Biotechnol Bioeng. 2012; 109(7): 1817-26.

PubMed Abstract | Publisher Full Text

5. Osiecki MJ, Michl TD, Kul Babur B, et al.: Packed Bed Bioreactor for the Isolation and Expansion of Placental-Derived Mesenchymal Stromal Cells. PLOS One. 2015; 10(12): e0144941

PubMed Abstract | Publisher Full Text | Free Full Text

6. F Grein TA, Leber J, Blumenstock M, et al:: Multiphase mixing characteristics in a microcarrier-based stirred tank bioreactor suitable for human mesenchymal stem cell expansion. Process Biochem. 2016; 51(9): 1109-19. Publisher Full Text | F1000 Recommendation

7. F Surrao DC, Boon K, Borys B, et al:: Large-scale expansion of human skinderived precursor cells (hSKPs) in stirred suspension bioreactors. Biotechnol Bioeng. 2016; 113(12): 2725-38

PubMed Abstract | Publisher Full Text | F1000 Recommendation

8. Gasperini L, Mano JF, Reis RL: Natural polymers for the microencapsulation of cells. J R Soc Interface 2014; 11(100): 20140817. PubMed Abstract | Publisher Full Text | Free Full Text

9. F Doméjean $\mathrm{H}$, de la Motte Saint Pierre M, Funfak A, et al:: Controlled production of sub-millimeter liquid core hydrogel capsules for parallelized 3D cell culture. Lab Chip. 2016; 17(1): 110-9.

PubMed Abstract | Publisher Full Text | F1000 Recommendation

10. Yasuda $\mathrm{S}$, Ikeda $\mathrm{T}$, Shahsavarani $\mathrm{H}$, et al.: Chemically defined and growth-factorfree culture system for the expansion and derivation of human pluripotent stem cells. Nat Biomed Eng. 2018; 2: 173-82. Publisher Full Text

11. F Lawson T, Kehoe DE, Schnitzler AC, et al.: Process development for expansion of human mesenchymal stromal cells in a $50 \mathrm{~L}$ single-use stirred tank bioreactor. Biochem Eng J. 2017; 120: 49-62.

Publisher Full Text | F1000 Recommendation

12. Schirmaier C, Jossen V, Kaiser SC, et al:: Scale-up of adipose tissue-derived mesenchymal stem cell production in stirred single-use bioreactors under low-serum conditions. Eng Life Sci. 2014; 14(3): 292-303. Publisher Full Text

13. Hutton DL, Moore EM, Gimble JM, et al:: Platelet-derived growth factor and spatiotemporal cues induce development of vascularized bone tissue by adipose-derived stem cells. Tissue Eng Part A. 2013; 19(17-18): 2076-86. PubMed Abstract | Publisher Full Text | Free Full Text

14. Tsai A, Liu Y, Yuan X, et al:: Compaction, fusion, and functional activation of three-dimensional human mesenchymal stem cell aggregate. Tissue Eng Part A. 2015; 21(9-10): 1705-19.

PubMed Abstract | Publisher Full Text | Free Full Text

15. Kapur SK, Wang $X$, Shang $H$, et al:: Human adipose stem cells maintain proliferative, synthetic and multipotential properties when suspension cultured as self-assembling spheroids. Biofabrication. 2012; 4(2): 025004 PubMed Abstract | Publisher Full Text | Free Full Text

16. F Tsai A, Liu Y, Yuan X, et al:: Aggregation kinetics of human mesenchymal stem cells under wave motion. Biotechnol J. 2017; 12(5): 1600448. PubMed Abstract | Publisher Full Text | F1000 Recommendation

17. Markert S, Joeris K: Establishment of a fully automated microtiter plate-based system for suspension cell culture and its application for enhanced process optimization. Biotechnol Bioeng. 2017; 114(1): 113-21.

PubMed Abstract | Publisher Full Text

18. Varley MC, Markaki AE, Brooks RA: Effect of Rotation on Scaffold Motion and Cell Growth in Rotating Bioreactors. Tissue Eng Part A. 2017; 23(11-12): 522-34. PubMed Abstract | Publisher Full Text | Free Full Text

19. F Nguyen BN, Ko H, Fisher JP: Tunable osteogenic differentiation of hMPCs in tubular perfusion system bioreactor. Biotechnol Bioeng. 2016; 113(8): 1805-13.

PubMed Abstract | Publisher Full Text | F1000 Recommendation

20. F Ball O, Nguyen BB, Placone JK, et al:: 3D Printed Vascular Networks Enhance Viability in High-Volume Perfusion Bioreactor. Ann Biomed Eng. 2016; 44(12): 3435-45.

PubMed Abstract | Publisher Full Text | Free Full Text | F1000 Recommendation

21. F Mock U, Nickolay L, Philip B, et al.: Automated manufacturing of chimeric antigen receptor $\mathrm{T}$ cells for adoptive immunotherapy using CliniMACS prodigy. Cytotherapy. 2016; 18(8): 1002-11.

PubMed Abstract | Publisher Full Text | F1000 Recommendation

22. F Priesner C, Aleksandrova K, Esser R, et al.: Automated Enrichment, Transduction, and Expansion of Clinical-Scale CD62L+T Cells for Manufacturing of Gene Therapy Medicinal Products. Hum Gene Ther. 2016; 27(10): 860-9.

PubMed Abstract | Publisher Full Text | Free Full Text | F1000 Recommendation

23. Wang $Y$, Cheng L, Gerecht S: Efficient and scalable expansion of human pluripotent stem cells under clinically compliant settings: a view in 2013. Ann Biomed Eng. 2014; 42(7): 1357-72.

PubMed Abstract | Publisher Full Text | Free Full Text

24. Kropp C, Massai D, Zweigerdt R: Progress and challenges in large-scale expansion of human pluripotent stem cells. Process Biochem. 2017;
59(Part B): 244-54

Publisher Full Text

25. F Abecasis B, Aguiar T, Arnault É, et al.: Expansion of 3D human induced pluripotent stem cell aggregates in bioreactors: Bioprocess intensification and scaling-up approaches. J Biotechnol. 2017; 246: 81-93. PubMed Abstract | Publisher Full Text | F1000 Recommendation

26. Wang $X$, Rivière I: Clinical manufacturing of CAR T cells: foundation of a promising therapy. Mol Ther Oncolytics. 2016; 3: 16015.

PubMed Abstract | Publisher Full Text | Free Full Text

27. Kaiser AD, Assenmacher M, Schröder B, et al:: Towards a commercial process for the manufacture of genetically modified $\mathrm{T}$ cells for therapy. Cancer Gene Ther. 2015; 22(2): 72-8

PubMed Abstract | Publisher Full Text | Free Full Text

28. Norkin M, Wingard JR: Recent advances in hematopoietic stem cell transplantation [version 1; referees: 2 approved]. F1000Res. 2017; 6: 870 PubMed Abstract | Publisher Full Text | Free Full Text

29. Maus MV, Nikiforow S: The Why, what, and How of the New FACT standards for immune effector cells. J Immunother Cancer. 2017; 5: 36. PubMed Abstract | Publisher Full Text | Free Full Text

30. Stoppel WL, Kaplan DL, Black LD 3rd: Electrical and mechanical stimulation of cardiac cells and tissue constructs. Adv Drug Deliv Rev. 2016; 96: 135-55. PubMed Abstract | Publisher Full Text | Free Full Text

31. F Luciani N, Du V, Gazeau F, et al:: Successful chondrogenesis within scaffolds, using magnetic stem cell confinement and bioreactor maturation. Acta Biomater. 2016; 37: 101-10. PubMed Abstract | Publisher Full Text | F1000 Recommendation

32. F Dikina AD, Lai BP, Cao M, et al.: Magnetic field application or mechanical stimulation via magnetic microparticles does not enhance chondrogenesis in mesenchymal stem cell sheets. Biomater Sci. 2017; 5(7): 1241-5. PubMed Abstract | Publisher Full Text | Free Full Text | F1000 Recommendation

33. F Guo T, Yu L, Lim CG, et al:: Effect of Dynamic Culture and Periodic Compression on Human Mesenchymal Stem Cell Proliferation and Chondrogenesis. Ann Biomed Eng. 2016; 44(7): 2103-13. PubMed Abstract | Publisher Full Text | Free Full Text | F1000 Recommendation

34. F Mellor LF, Steward AJ, Nordberg RC, et al:: Comparison of Simulated Microgravity and Hydrostatic Pressure for Chondrogenesis of hASC. Aerosp Med Hum Perform. 2017; 88(4): 377-84. PubMed Abstract | Publisher Full Text | F1000 Recommendation

35. F Gharravi AM, Orazizadeh M, Hashemitabar M: Fluid-induced low shear stress improves cartilage like tissue fabrication by encapsulating chondrocytes. Cell Tissue Bank. 2016; 17(1): 117-22. PubMed Abstract | Publisher Full Text | F1000 Recommendation

36. $\mathrm{F}$ Hendrikson WJ, Deegan AJ, Yang Y, et al.: Influence of Additive Manufactured Scaffold Architecture on the Distribution of Surface Strains and Fluid Flow Shear Stresses and Expected Osteochondral Cell Differentiation. Front Bioeng Biotechnol. 2017: 5: 6 .

PubMed Abstract | Publisher Full Text | Free Full Text | F1000 Recommendation

37. Coletti F, Macchietto S, Elvassore N: Mathematical Modeling of Three-Dimensional Cell Cultures in Perfusion Bioreactors. Ind Eng Chem Res. 2006; 45(24): 8158-69. Publisher Full Text

38. Shakeel M, Matthews PC, Graham RS, et al:: A continuum model of cell proliferation and nutrient transport in a perfusion bioreactor. Math Med Biol. 2013; 30(1): 21-44.

PubMed Abstract | Publisher Full Text

39. Flaibani M, Magrofuoco E, Elvassore N: Computational Modeling of Cell Growth Heterogeneity in a Perfused 3D Scaffold. Ind Eng Chem Res. 2010; 49(2): 859-69. Publisher Full Text

40. F Guyot Y, Papantoniou I, Luyten FP, et al:: Coupling curvature-dependent and shear stress-stimulated neotissue growth in dynamic bioreactor cultures: a 3D computational model of a complete scaffold. Biomech Model Mechanobiol 2016; 15(1): 169-80.

PubMed Abstract | Publisher Full Text | F1000 Recommendation

41. F Bhumiratana S, Bernhard JC, Alfi DM, et al:: Tissue-engineered autologous grafts for facial bone reconstruction. Sci Transl Med. 2016; 8(343): 343ra83. PubMed Abstract | Publisher Full Text | Free Full Text | F1000 Recommendation

42. $\mathrm{F}$ Nguyen BN, Ko H, Moriarty RA, et al:: Dynamic Bioreactor Culture of High Volume Engineered Bone Tissue. Tissue Eng Part A. 2016; 22(3-4): 263-71. PubMed Abstract | Publisher Full Text | Free Full Text | F1000 Recommendation

43. Huang R, Kobayashi E, Liu K, et al:: Bone Graft Prefabrication Following the In Vivo Bioreactor Principle. EBioMedicine. 2016; 12: 43-54. PubMed Abstract | Publisher Full Text | Free Full Text

44. Wei J, Herrler T, Liu K, et al:: The Role of Cell Seeding, Bioscaffolds, and the In Vivo Microenvironment in the Guided Generation of Osteochondral Composite Tissue. Tissue Eng Part A. 2016; 22(23-24): 1337-47. PubMed Abstract | Publisher Full Text

45. $\mathrm{F}$ Zhao $\mathrm{L}, \mathrm{Zhao} \mathrm{J}, \mathrm{Yu} \mathrm{J}$, et al:: In vivo investigation of tissue-engineered periosteum for the repair of allogeneic critical size bone defects in rabbits. Regen Med. 2017; 12(4): 353-64.

PubMed Abstract | Publisher Full Text | F1000 Recommendation 
46. Kaempfen A, Todorov A, Güven S, et al:: Engraftment of Prevascularized, Tissue Engineered Constructs in a Novel Rabbit Segmental Bone Defect Model. Int $J$ Mol Sci. 2015; 16(6): 12616-30.

PubMed Abstract | Publisher Full Text | Free Full Text

47. F Ma D, Ren L, Cao Z, et al:: Prefabrication of axially vascularized bone by combining $\beta$-tricalciumphosphate, arteriovenous loop, and cell sheet technique. Tissue Eng Regen Med. 2016; 13(5): 579-84. Publisher Full Text | F1000 Recommendation

48. Melville JC, Tursun R, Green JM 3rd, et al:: Reconstruction of a PostTraumatic Maxillary Ridge Using a Radial Forearm Free Flap and Immediate Tissue Engineering (Bone Morphogenetic Protein, Bone Marrow Aspirate Concentrate, and Cortical-Cancellous Bone): Case Report. J Oral Maxillofac Surg. 2017; 75(2): 438.e1-438.e6. PubMed Abstract | Publisher Full Text

49. Kasper FK, Melville J, Shum J, et al.: Tissue Engineered Prevascularized Bone and Soft Tissue Flaps. Oral Maxillofac Surg Clin North Am. 2017; 29(1): 63-73. PubMed Abstract | Publisher Full Text

50. Wiltfang J, Rohnen M, Egberts JH, et al: Man as a Living Bioreactor: Prefabrication of a Custom Vascularized Bone Graft in the Gastrocolic Omentum. Tissue Eng Part C Methods. 2016; 22(8): 740-6. PubMed Abstract | Publisher Full Text

51. F Hollister SJ, Flanagan CL, Morrison RJ, et al:: Integrating Image-Based Design and 3D Biomaterial Printing To Create Patient Specific Devices within a Design Control Framework for Clinical Translation. ACS Biomater Sci Eng. 2016; 2(10): 1827-36.

Publisher Full Text | F1000 Recommendation

52. $\mathrm{F}$ Tatara AM, Shah SR, Demian N, et al:: Reconstruction of large mandibular defects using autologous tissues generated from in vivo bioreactors. Acta Biomater. 2016; 45: 72-84. PubMed Abstract | Publisher Full Text | F1000 Recommendation

53. Warnke PH, Springer IN, Wiltfang J, et al:: Growth and transplantation of a custom vascularised bone graft in a man. Lancet. 2004; 364(9436): 766-70. PubMed Abstract | Publisher Full Text

54. Lee H, Cho DW: One-step fabrication of an organ-on-a-chip with spatial heterogeneity using a 3D bioprinting technology. Lab Chip. 2016; 16(14): 2618-25. PubMed Abstract | Publisher Full Text

55. Stucki AO, Stucki JD, Hall SR, et al.: A lung-on-a-chip array with an integrated bio-inspired respiration mechanism. Lab Chip. 2015; 15(5): 1302-10. PubMed Abstract | Publisher Full Text

56. $\mathrm{F}$ Benam $\mathrm{KH}$, Villenave $\mathrm{R}$, Lucchesi $\mathrm{C}$, et al.: Small airway-on-a-chip enables analysis of human lung inflammation and drug responses in vitro. Nat Methods. 2016; 13(2): 151-7.

PubMed Abstract | Publisher Full Text | F1000 Recommendation

57. F Zhang B, Montgomery M, Chamberlain MD, et al:: Biodegradable scaffold with built-in vasculature for organ-on-a-chip engineering and direct surgical anastomosis. Nat Mater. 2016; 15(6): 669-78. PubMed Abstract | Publisher Full Text | Free Full Text | F1000 Recommendation

58. F Kolesky DB, Homan KA, Skylar-Scott MA, et al:: Three-dimensional bioprinting of thick vascularized tissues. Proc Natl Acad Sci U S A. 2016; 113(12): 3179-84.

PubMed Abstract | Publisher Full Text | Free Full Text | F1000 Recommendation

59. F Cho S, Islas-Robles A, Nicolini AM, et al:: In situ, dual-mode monitoring of organ-on-a-chip with smartphone-based fluorescence microscope. Biosens Bioelectron. 2016; 86: 697-705.

PubMed Abstract | Publisher Full Text | Free Full Text | F1000 Recommendation

60. F Sutton A, Shirman T, Timonen JV, et al:: Photothermally triggered actuation of hybrid materials as a new platform for in vitro cell manipulation. Nat Commun. 2017; 8: 14700 .

PubMed Abstract | Publisher Full Text | Free Full Text | F1000 Recommendation

51. $\mathrm{F}$ Lee H, Kim DS, Ha SK, et al.: A pumpless multi-organ-on-a-chip (MOC) combined with a pharmacokinetic-pharmacodynamic (PK-PD) model. Biotechnol Bioeng. 2017; 114(2): 432-43.

PubMed Abstract | Publisher Full Text | F1000 Recommendation

62. F Shirure VS, George SC: Design considerations to minimize the impact of drug absorption in polymer-based organ-on-a-chip platforms. Lab Chip. 2017; 17(4): 681-90.

PubMed Abstract | Publisher Full Text | F1000 Recommendation 


\section{Open Peer Review}

\section{Current Peer Review Status:}

\section{Editorial Note on the Review Process}

Faculty Reviews are review articles written by the prestigious Members of Faculty Opinions. The articles are commissioned and peer reviewed before publication to ensure that the final, published version is comprehensive and accessible. The reviewers who approved the final version are listed with their names and affiliations.

\section{The reviewers who approved this article are:}

\section{Version 1}

\section{Liesbet Geris}

1 Biomechanics Section, KU Leuven, Leuven, Belgium

2 GIGA In silico medicine, University of Liège, Liège, Belgium

Ioannis Papantoniou

Skeletal Biology \& Engineering Research Center, KU Leuven, Leuven, Belgium

Priyanka Gupta

Skeletal Biology \& Engineering Research Center, KU Leuven, Leuven, Belgium

Competing Interests: No competing interests were disclosed.

\section{Teng Ma}

Department of Chemical and Biomedical Engineering, Florida State University, Tallahassee, Florida, USA

Competing Interests: Warren Grayson was a PhD student in Teng Ma's Lab 12 years ago.

The benefits of publishing with F1000Research:

- Your article is published within days, with no editorial bias

- You can publish traditional articles, null/negative results, case reports, data notes and more

- The peer review process is transparent and collaborative

- Your article is indexed in PubMed after passing peer review

- Dedicated customer support at every stage

For pre-submission enquiries, contact research@f1000.com 